U.S. Air Force, Aeronautical Systems Center,

Environmental Management Directorate, Wright-Patterson Air Force Base, Ohio

\title{
Two-Dimensional Resistivity Investigation Along West Fork Trinity River, Naval Air Station-Joint Reserve Base Carswell Field, Fort Worth, Texas, October 2004
}

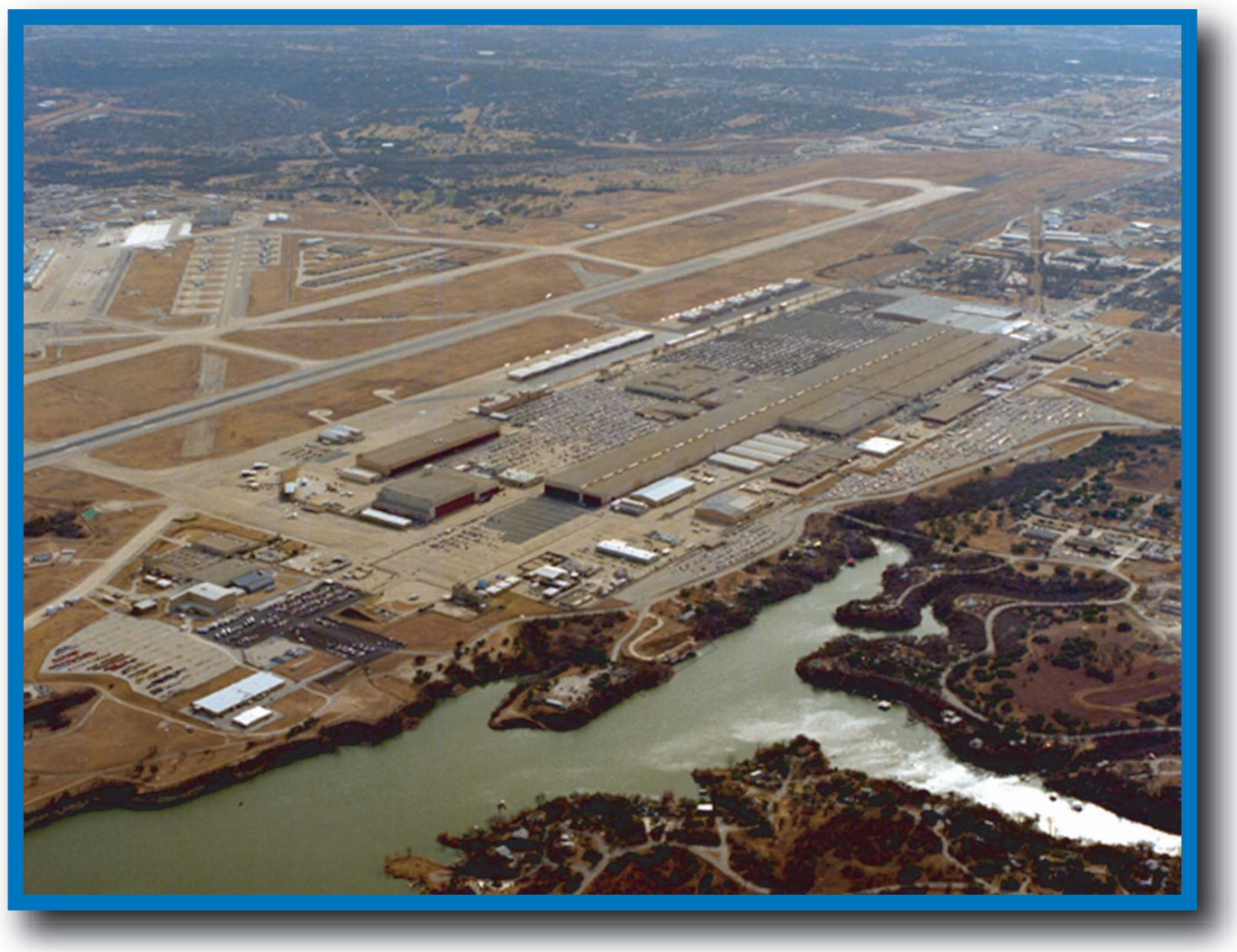

Data Series 178 
Blank Page 


\section{Two-Dimensional Resistivity Investigation Along West Fork Trinity River, Naval Air Station-Joint Reserve Base Carswell Field, Fort Worth, Texas, October 2004}

By Sachin D. Shah and Gregory P. Stanton

In cooperation with the U.S. Air Force, Aeronautical Systems Center,

Environmental Management Directorate, Wright-Patterson Air Force Base, Ohio

Data Series 178 


\section{U.S. Department of the Interior Gale A. Norton, Secretary}

\section{U.S. Geological Survey \\ P. Patrick Leahy, Acting Director}

\section{U.S. Geological Survey, Reston, Virginia: 2006}

For sale by U.S. Geological Survey, Information Services

Box 25286, Denver Federal Center

Denver, CO 80225

For more information about the USGS and its products:

Telephone: 1-888-ASK-USGS

World Wide Web: http://www.usgs.gov/

Any use of trade, product, or firm names in this publication is for descriptive purposes only and does not imply endorsement by the U.S. Government.

Although this report is in the public domain, permission must be secured from the individual copyright owners to reproduce any copyrighted materials contained within this report.

Suggested citation:

Shah, S.D., and Stanton, G.P., 2006, Two-dimensional resistivity investigation along West Fork Trinity River, Naval Air Station-Joint Reserve Base Carswell Field, Fort Worth, Texas, October 2004: U.S. Geological Survey Data Series 178, 24 p. 


\section{Contents}

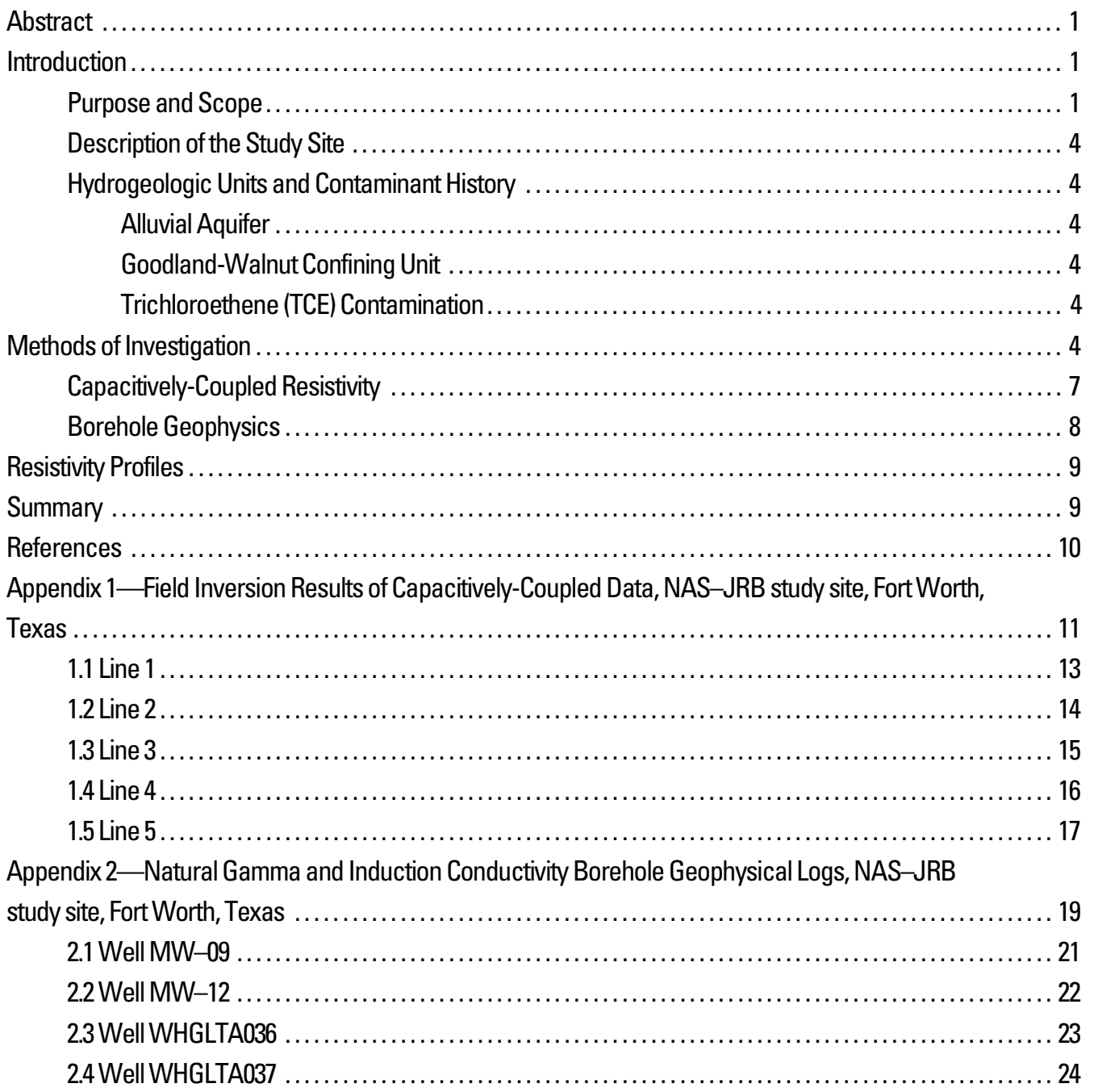

\section{Figures}

\section{1-4. Maps showing:}

1. Location of Naval Air Station-Joint Reserve Base Carswell Field (NAS-JRB), Fort

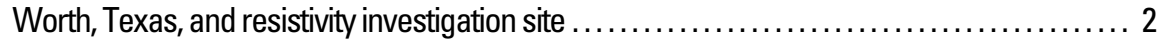

2. Location of two-dimensional (2D) capacitively-coupled resistivity profiles and wells, NAS-JRB study site, Fort Worth, Texas ...................................... 3

3. Water-table (potentiometric surface) of the alluvial aquifer and general directions of ground-water flow, NAS-JRB, Fort Worth, Texas, fall 2002 ...................... 5

4. Extent of trichloroethene (TCE) plume in the alluvial aquifer, NAS-JRB, Fort Worth, Texas, October 2002

5. Diagrams showing field inversion results of capacitively-coupled data (actual resistivity) at common resistivity scale for lines $1-5$, NAS-JRB study site, Fort Worth, Texas. 


\section{Table}

1. Well completion information for wells logged during October 2004, NAS-JRB study site, Fort Worth, Texas

\section{Vertical and Horizontal Datums}

Vertical coordinate information is referenced to the North American Vertical Datum of 1988 (NAVD 88).

Horizontal coordinate information is referenced to the North American Datum of 1983 (NAD 83).

Altitude, as used in this report, refers to distance above the vertical datum. 


\title{
Two-Dimensional Resistivity Investigation Along West Fork Trinity River, Naval Air Station-Joint Reserve Base Carswell Field, Fort Worth, Texas, October 2004
}

\author{
By Sachin D. Shah and Gregory P. Stanton
}

\section{Abstract}

Naval Air Station-Joint Reserve Base Carswell Field (NAS-JRB) at Fort Worth, Tex., constitutes a governmentowned, contractor-operated facility that has been in operation since 1942. Contaminants, primarily volatile organic compounds and metals, have entered the ground-water-flow system through leakage from waste-disposal sites and manufacturing processes. Ground water flows from west to east toward the West Fork Trinity River. During October 2004, the U.S. Geological Survey conducted a two-dimensional (2D) resistivity investigation at a site along the West Fork Trinity River at the eastern boundary of NAS-JRB to characterize the distribution of subsurface resistivity. Five 2D resistivity profiles were collected, which ranged from 500 to 750 feet long and extended to a depth of 25 feet. The Goodland Limestone and the underlying Walnut Formation form a confining unit that underlies the alluvial aquifer. The top of this confining unit is the top of bedrock at NAS-JRB. The bedrock confining unit is the zone of interest because of the potential for contaminated ground water to enter the West Fork Trinity River through saturated bedrock. The study involved a capacitively-coupled resistivity survey and inverse modeling to obtain true or actual resistivity from apparent resistivity. The apparent resistivity was processed using an inverse modeling software program. The results of this program were used to generate distributions (images) of actual resistivity referred to as inverted sections or profiles. The images along the five profiles show a wide range of resistivity values. The two profiles nearest the West Fork Trinity River generally showed less resistivity than the three other profiles.

\section{Introduction}

During October 2004, the U.S. Geological Survey (USGS), in cooperation with the U.S. Air Force, Aeronautical
Systems Center Environmental Management Directorate (ASC/ENVR), conducted a two-dimensional (2D) resistivity investigation at the Naval Air Station-Joint Reserve Base Carswell Field (NAS-JRB) at Fort Worth, Tex. (fig. 1). NAS-JRB constitutes a government-owned, contractor-operated facility that has been in operation since 1942. Contaminants from the facility, primarily volatile organic compounds (VOCs) and metals, have entered the ground-water-flow system through leakage from waste-disposal sites (landfills and pits) and from manufacturing processes (U.S. Army Corps of Engineers, 1986; Jacobs Engineering Group, Inc., 1993; RUST Geotech, 1995a, b, c, d). These contaminants are of concern to the citizens of Fort Worth, as well as agencies responsible for water quality because of the potential for VOCs to enter the West Fork Trinity River east of NAS-JRB.

The resistivity investigation was done to characterize the shallow (25 feet [ft] or less) subsurface distribution of electrical resistivity, which can be used to obtain the depth and distribution of saturated bedrock, at a site along the West Fork Trinity River at the eastern boundary of NAS-JRB. Five capacitivelycoupled resistivity profiles (lines) were collected along the West Fork Trinity River. The profiles range in length from 500 to $750 \mathrm{ft}$ (fig. 2) and extended to a depth of $25 \mathrm{ft}$. Natural gamma and induction conductivity borehole geophysical logs also were obtained from four wells.

\section{Purpose and Scope}

This report describes the methods used in the 2D resistivity investigation along the West Fork Trinity River, NAS-JRB, and presents the resistivity data collected. The report documents the inversion results of the five capacitively-coupled resistivity surveys collected at the site. The data for the lines are described and presented graphically in the form of 2D distributions (images) of resistivity along the West Fork Trinity River. Borehole geophysical logs of four wells at the study site also are documented. Following a brief description of the hydrogeology 


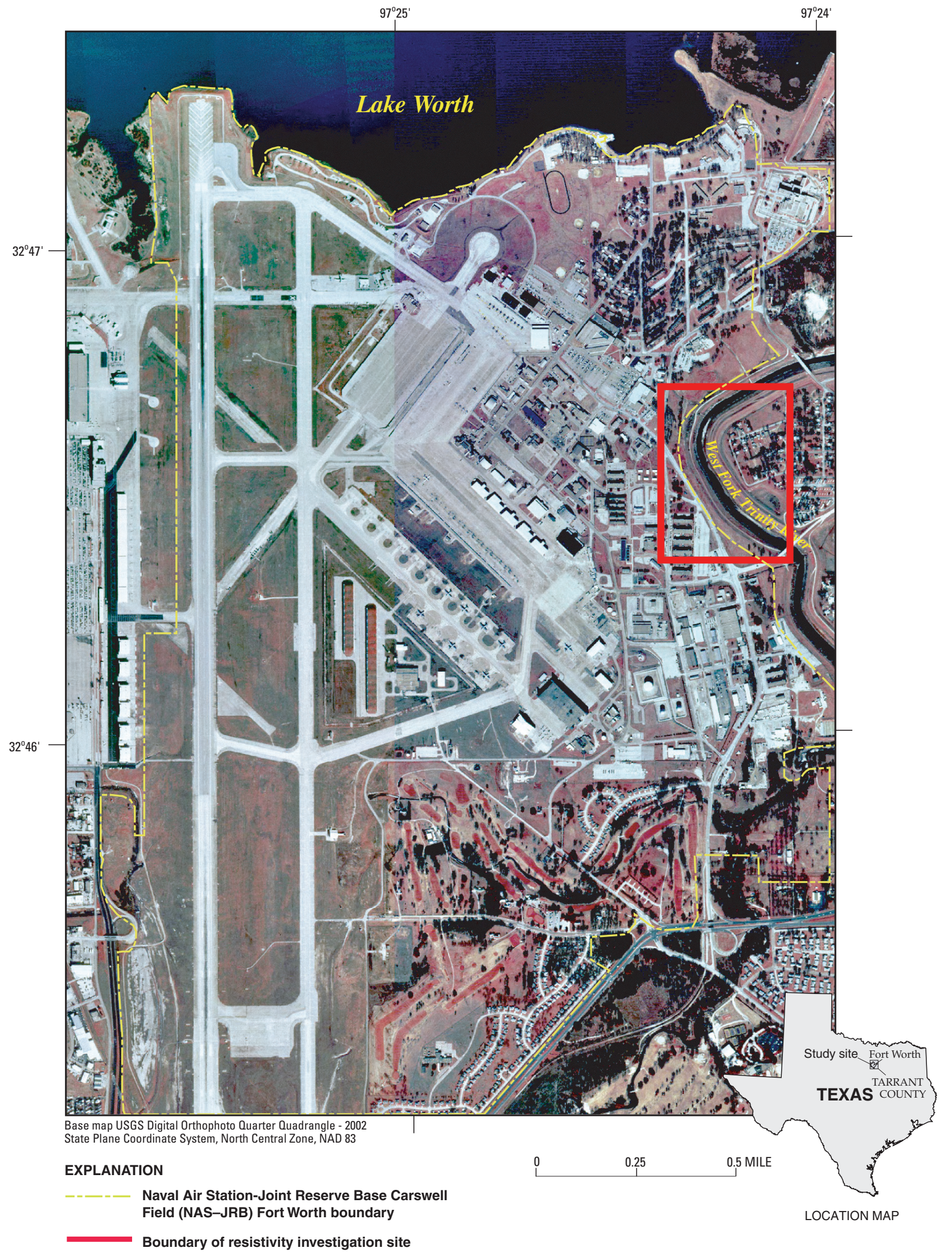

Figure 1. Location of Naval Air Station-Joint Reserve Base Carswell Field (NAS-JRB), Fort Worth, Texas, and resistivity investigation site. 


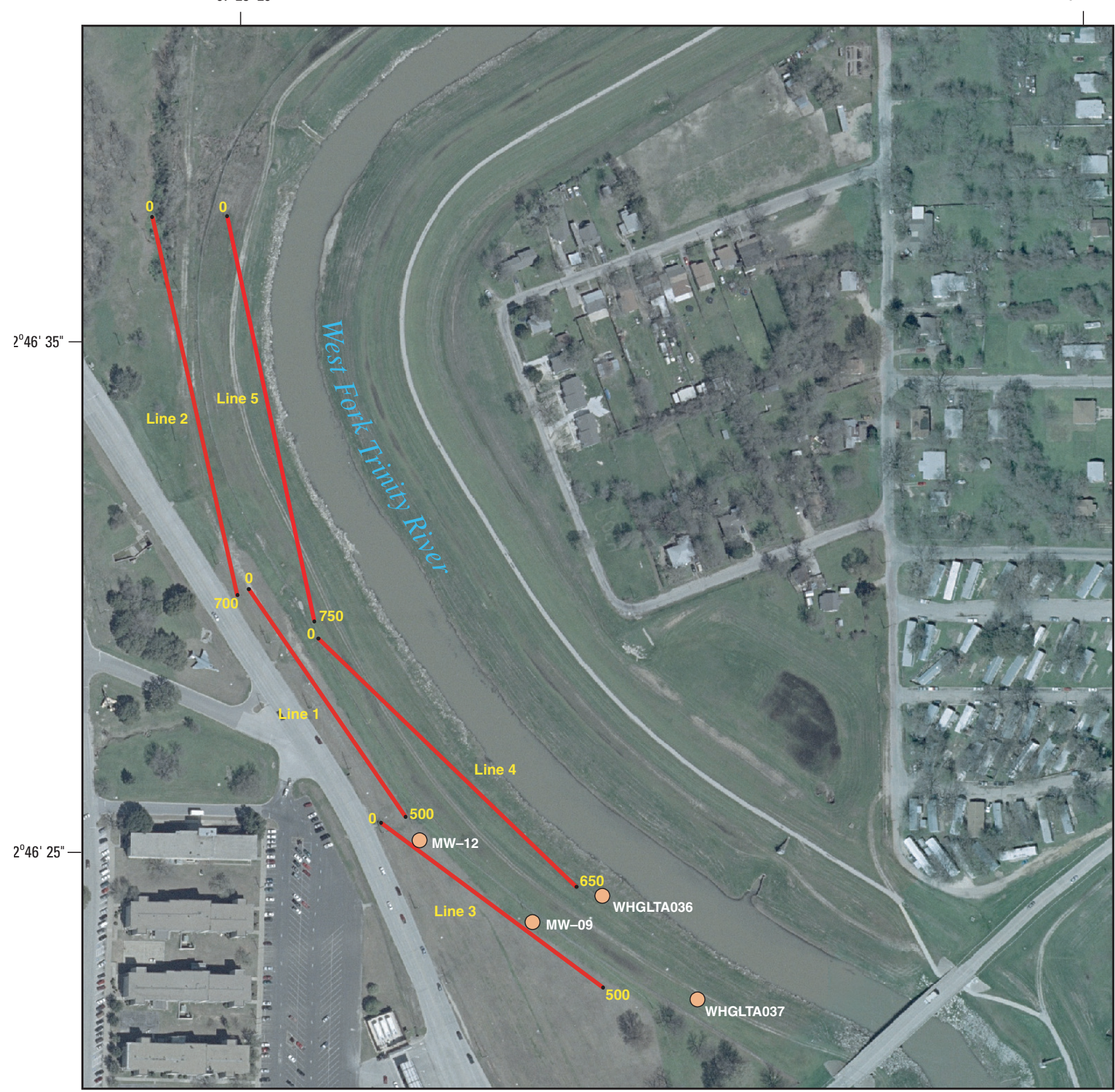

Base map USGS Digital Orthophoto Quarter Quadrangle - 2002 State Plane Coordinate System, North Central Zone, NAD 83

EXPLANATION
$\begin{aligned} & \text { Line } 1 \\ & \text { Two-dimensional capacitively- } \\ & \text { coupled resistivity survey line } \\ & \text { and label-Number indicates } \\ & \text { length, in feet } \\ & \text { MW-12 } \\ & \text { Borehole geophysical logged } \\ & \text { monitoring well location and } \\ & \text { number }\end{aligned}$

Figure 2. Location of two-dimensional (2D) capacitively-coupled resistivity profiles and wells, NAS-JRB study site, Fort Worth, Texas. 
and contaminant history of NAS-JRB, the report explains 2D surface resistivity, and gamma and induction borehole geophysical methods and their application to characterize shallow subsurface areas. Interpretation of the resistivity distributions to identify saturated bedrock at the site was not within the scope of this report.

\section{Description of the Study Site}

The NAS-JRB study site is in the east-central part of NAS-JRB and mostly includes the eastern boundary of NAS-JRB and part of the western levee of the West Fork Trinity River. Land-surface altitudes range from about $585 \mathrm{ft}$ above NAVD 88 along the southern boundary of the site to about $610 \mathrm{ft}$ above NAVD 88 . The site is drained primarily by the West Fork Trinity River (Shah, 2004).

NAS-JRB opened as Tarrant Field Airdrome and was used to train pilots under the jurisdiction of the Gulf Coast Army Air Field Training Command (HydroGeoLogic, Inc., 2002). In 1948, the base was renamed Carswell Air Force Base, and the Seventh Bomber Wing became the host unit. In 1994, the U.S. Navy assumed responsibility for much of the facility, and its name was changed from Carswell Air Force Base to NAS-JRB.

\section{Hydrogeologic Units and Contaminant History}

Aspects of the hydrogeology beneath the facility have been described in several recent USGS reports (for example, Kuniansky and others, 1996; Shah, 2004). From oldest to youngest, the Cretaceous rocks that crop out near NAS-JRB are the Paluxy Formation, Walnut Formation, and Goodland Limestone. These rocks are overlain by Quaternary alluvial deposits (primarily silt, clay, and gravel) and some fill material, the combined thickness of which ranges from negligible to about $20 \mathrm{ft}$ at the study site. In the subsurface of the study site, the geologic (stratigraphic) units and the hydrogeologic units (aquifer and confining unit) are coincident.

The alluvial deposits and the Paluxy Formation constitute aquifers-the alluvial aquifer and the Paluxy aquifer. The Goodland Limestone and the underlying Walnut Formation together constitute a confining unit, the Goodland-Walnut confining unit, which separates the two aquifers. This confining unit forms the top of bedrock at NAS-JRB. This bedrock confining unit is the zone of interest in this investigation because of the potential for contaminated ground water to enter the West Fork Trinity River through saturated bedrock; the Paluxy aquifer is not considered in this report.

\section{Alluvial Aquifer}

The alluvial aquifer at the site consists primarily of clay and silt with sand and gravel deposits and ranges in thickness from about 5 to $25 \mathrm{ft}$ (Shah, 2004, fig. 8). The alluvial aquifer is recharged locally by precipitation. A potentiometric-surface map constructed from data collected during fall 2002 (Shah, 2004) indicates ground water flows generally from west to east (fig. 3). However, ground water moves at different rates locally because of the heterogeneous nature of the aquifer, which results in preferred flow paths in the sand and gravel channel deposits. Flow velocities tend to be greater in sand and gravel deposits than in the adjacent clay and silt (Shah, 2004). Thus, ground-water movement probably varies between the two general lithologies of the alluvial aquifer.

\section{Goodland-Walnut Confining Unit}

The Goodland-Walnut confining unit directly underlies the alluvial aquifer and forms the top of bedrock at NAS-JRB. The upper part of the unit, the Goodland Limestone, consists of massive fossiliferous limestone interbedded with marl and shale (Shah, 2004). The Goodland Limestone mostly has been eroded at the NAS-JRB and only remnants of it overlie the Walnut Formation, the lower part of the confining unit. The Walnut Formation consists of clay and limestone.

The Goodland-Walnut confining unit ranges in thickness from negligible to about $25 \mathrm{ft}$ at the study site (Shah, 2004, fig. 11). The Goodland-Walnut confining unit has very low permeability over much of NAS-JRB.

\section{Trichloroethene (TCE) Contamination}

Several VOCs have been detected in ground-water samples from the alluvial aquifer at NAS-JRB. A VOC of principal concern is TCE. TCE is a dense nonaqueous-phase liquid and a solvent used for degreasing metal parts in the manufacture of airplanes (Shah, 2004). TCE was stored in a chemical processing facility at the adjacent Air Force Plant 4, immediately west of the NAS-JRB, and entered the alluvial aquifer by leakage from the surface (U.S. Air Force, Aeronautical Systems Center, 1995). Figure 4 shows the concentrations of TCE in the alluvial aquifer beneath NAS-JRB and indicates the extent of the TCE plume in October 2002 (Shah, 2004, fig. 4).

\section{Methods of Investigation}

Surface and borehole geophysical methods provide a relatively quick and inexpensive means to characterize the subsurface (Powers and others, 1999). These geophysical methods can be used to measure physical properties of the subsurface such as electrical conductivity and resistivity, dielectric permittivity, magnetic permeability, density, and acoustic velocity (Keys, 1997). These methods can be influenced by chemical and physical properties of soil, rock, and pore fluids. Interpretations from these measurements can be used to image the distribution of 
$97^{0} 25$

$97^{\circ} 24^{\prime}$

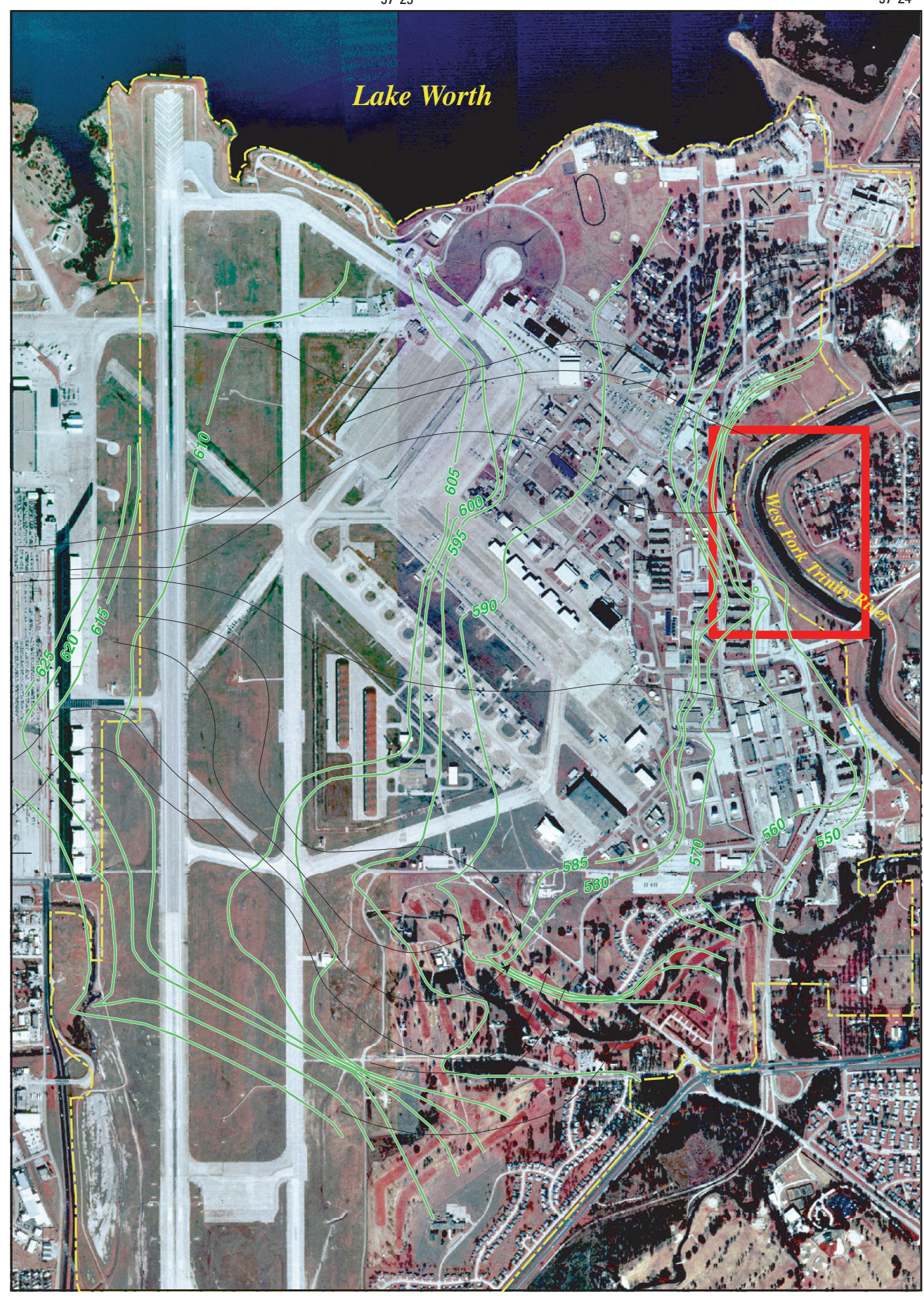

Base map USGS Digital Orthophoto Quarter Quadrangle - 2002

State Plane Coordinate System, North Central Zone, NAD 83

EXPLANATION

- NAS-JRB boundary

-610 Water table of the alluvial aquifer-Shows altitude at which water level would have stood in tightly cased well. Intervals 5 and 10 feet. Datum is NAVD 88

Boundary of resistivity investigation site

$\rightarrow \quad$ General direction of ground-water flow

Figure 3. Water-table (potentiometric surface) of the alluvial aquifer and general directions of ground-water flow, NAS-JRB, Fort Worth, Texas, fall 2002 (modified from Shah, 2004, fig. 3). 


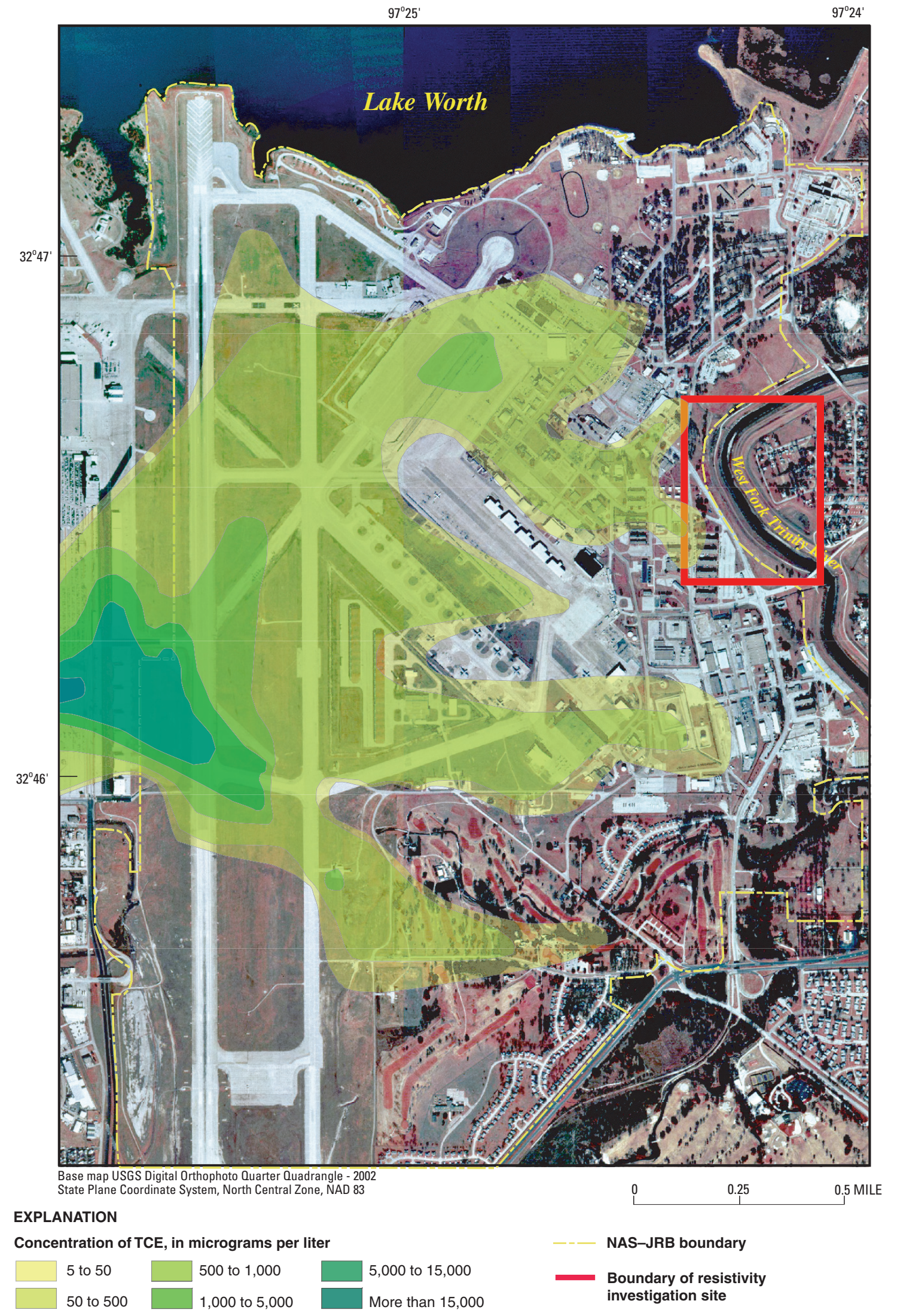

Figure 4. Extent of trichloroethene (TCE) plume in the alluvial aquifer, NAS-JRB, Fort Worth, Texas, October 2002 (modified from Shah, 2004, fig. 4). 
Table 1. Well completion information for wells logged during October 2004, NAS-JRB study site, Fort Worth, Texas (U.S. Air Force, Center for Environmental Excellence, 1997).

[NAS-JRB, Naval Air Station-Joint Reserve Base Carswell Field; USGS, U.S. Geological Survey; NAD 83, North American Datum of 1983; LSD, land surface datum; NAVD 88, Nation American Vertical Datum of 1988]

\begin{tabular}{|c|c|c|c|c|c|c|c|c|c|}
\hline $\begin{array}{c}\text { NAS-JRB } \\
\text { well ID } \\
\text { (fig. 2) }\end{array}$ & $\begin{array}{l}\text { USGS } \\
\text { site ID }\end{array}$ & $\begin{array}{l}\text { Latitude } \\
\text { NAD } 1983 \\
\text { (degrees, } \\
\text { minutes, } \\
\text { seconds) }\end{array}$ & $\begin{array}{c}\text { Longitude } \\
\text { NAD } 1983 \\
\text { (degrees, } \\
\text { minutes, } \\
\text { seconds) }\end{array}$ & $\begin{array}{c}\text { Altitude } \\
\text { of LSD } \\
\text { (feet } \\
\text { above } \\
\text { NAVD 88) }\end{array}$ & $\begin{array}{l}\text { Well } \\
\text { depth } \\
\text { (feet } \\
\text { below } \\
\text { LSD) }\end{array}$ & $\begin{array}{c}\text { Top of } \\
\text { Casing } \\
\text { (feet } \\
\text { above } \\
\text { NAVD 88) }\end{array}$ & $\begin{array}{c}\text { Borehole } \\
\text { diameter } \\
\text { (inches) }\end{array}$ & $\begin{array}{c}\text { Screen } \\
\text { length } \\
\text { (feet) }\end{array}$ & $\begin{array}{c}\text { Screen } \\
\text { slot } \\
\text { diameter } \\
\text { (inches) }\end{array}$ \\
\hline MW-12 & 324643097271201 & $32^{\circ} 46^{\prime} 42.8^{\prime \prime}$ & $97^{\circ} 27^{\prime} 11.6^{\prime \prime}$ & 560.17 & 28.2 & 560.5 & 4 & 10 & .01 \\
\hline WHGLTA036 & 324624097251201 & $32^{\circ} 46^{\prime} 24.1^{\prime \prime}$ & $97^{\circ} 25^{\prime} 11.7^{\prime \prime}$ & 555.57 & 16.1 & 556.0 & 4 & 10 & .01 \\
\hline WHGLTA037 & 324623097241001 & $32^{\circ} 46^{\prime} 23.1^{\prime \prime}$ & $97^{\circ} 25^{\prime} 10.1^{\prime \prime}$ & 556.46 & 15.8 & 556.5 & 4 & 10 & .01 \\
\hline
\end{tabular}

physical properties in the subsurface (American Society for Testing and Materials, 1999).

Electrical surface geophysical methods can be used to detect variations in the electrical properties of the subsurface. The electrical properties of soil and rock are controlled by water content, salt content, porosity, and the presence of metallic minerals. Variations in the electrical properties of soils and rocks, either vertically or horizontally, produce variations in the electrical signatures measured by surface geophysical tools.

Changes in the received signal can be related to changes in the composition, extent, and physical properties of subsurface soil and rock, to the extent that differences in lithology or rock type are accompanied by differences in resistivity (U.S. Army Corps of Engineers, 1995).

The main objective of borehole geophysics is to obtain more information about the subsurface than can be obtained from conventional drilling, sampling, and testing (Keys, 1997). Geophysical logs can be interpreted in terms of lithology, thickness, and continuity of aquifers and confining units. Permeability, porosity, density, and chemical and physical properties of ground water also can be interpreted. Logs have unique advantages over samples for monitoring in that they provide a continuous vertical profile of data rather than point values (Keys, 1997). Measurements are made by lowering different types of probes into a borehole; data are electronically transmitted to the surface and recorded in digital or analog format as a function of depth.

For this report, the $2 \mathrm{D}$ resistivity investigation involved a capacitively-coupled resistivity survey (running resistivity profiles) and application of electrical image-processing software (inverse modeling) to obtain distributions of true or actual resis- tivity from apparent resistivity (fig. 5; app. 1). True resistivity equals apparent resistivity only for a homogeneous, isotropic subsurface. To enhance the 2D resistivity data, natural gamma and induction conductivity data were collected in four wells (table 1) and used to compare borehole resistivity data with the surface geophysical data (app. 2).

\section{Capacitively-Coupled Resistivity}

Capacitively-coupled resistivity measures apparent resistivity of the earth using antennas in a dipole-dipole array (Geometrics, 2005). The Geometrics OhmMapper TR2, a mobile resistivity measuring system, was used to do the resistivity survey. This system uses one transmitter dipole and two receiver dipoles to transmit an electrical current into the subsurface and back. A series of voltage measurements is made along a profile by towing the transmitter-receiver array with constant spacing between the transmitter and receivers. The transmitter-receiver spacing is then changed, which changes the depth of signal penetration, and the array is again pulled along the same profile.

The result is another series of measurements that correspond to a greater depth (Geometrics, 2005). Because voltage equals current times resistance, when a constant current is transmitted, variations in the resistivity of subsurface materials alter the voltage received; and resistance is computed by dividing the voltage received by the current transmitted. The apparent resistivity of the subsurface is computed by multiplying the measured resistance by a geometric correction that is determined from the geometry and the spacing of the array (Loke, 2004). Actual resistivity was obtained from apparent resistivity using 


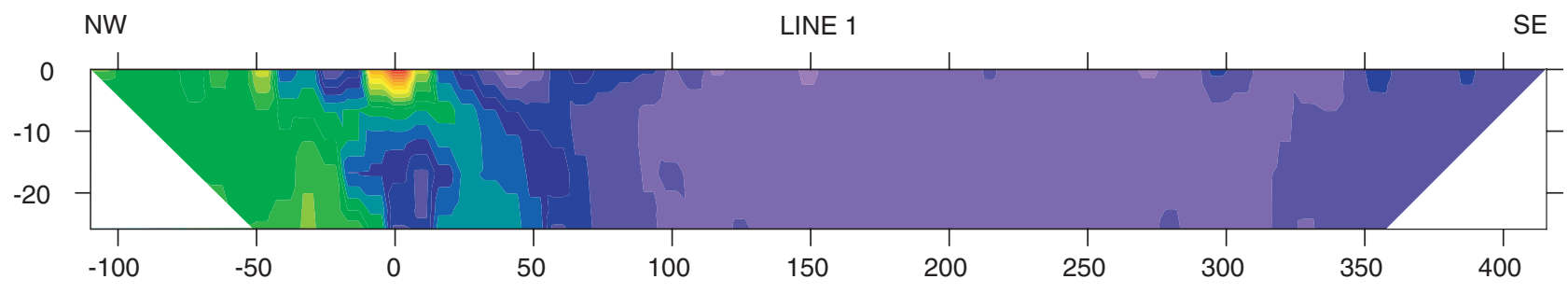

LINE 2

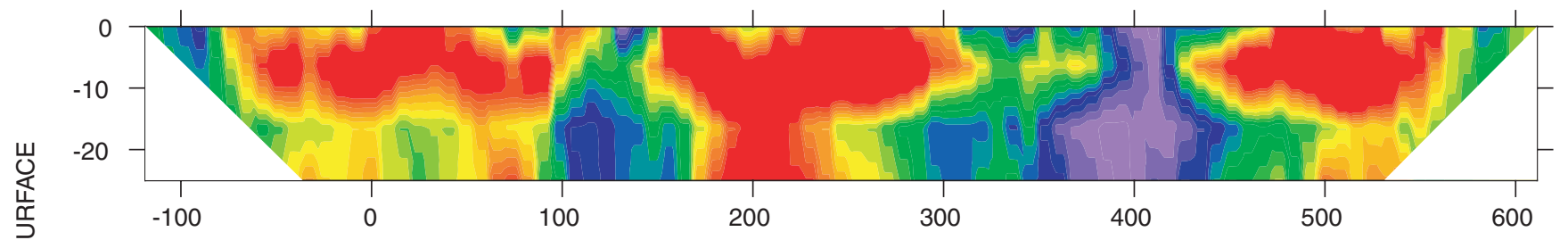

LINE 3
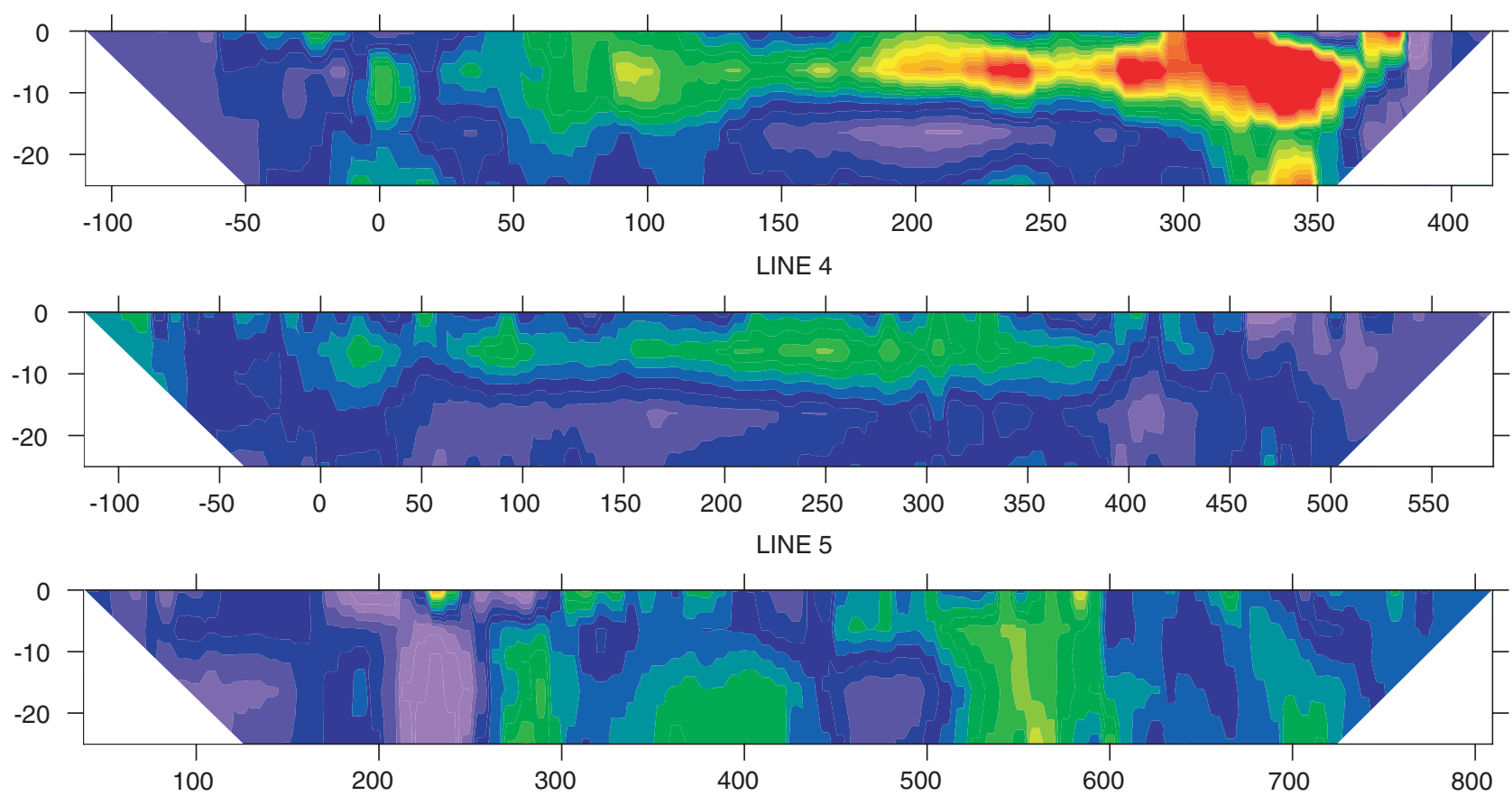

DISTANCE, IN FEET

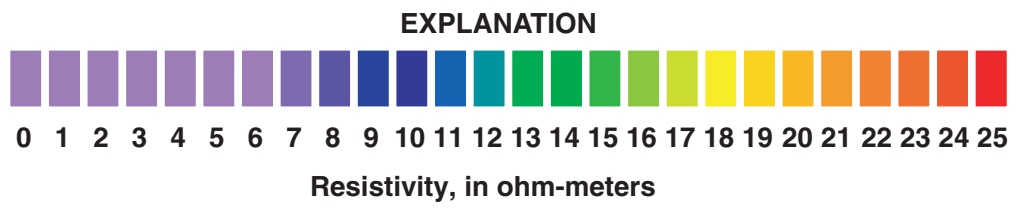

Figure 5. Field inversion results of capacitively-coupled data (actual resistivity) at common resistivity scale for lines 1-5, NAS-JRB study site, Fort Worth, Texas.

the 2D image-processing software Res2Dinv version 3.54

(Loke, 2005). Res2Dinv yields 2D images of actual subsurface resistivity (called inverted resistivity) along the profiles traversed to a depth (in this application) of $25 \mathrm{ft}$. The inverted field datasets were used to characterize the subsurface resistivity distribution (fig. 5; app. 1).

\section{Borehole Geophysics}

Natural gamma and induction conductivity geophysical logs were collected in four boreholes within the study site (app. 2). Natural gamma logs provide a record of total gamma radiation that is emitted from radioactive material in the rock 
adjacent to the borehole. Shales (clays), in general, have a higher concentration of radioactive material and therefore a higher gamma response on logs. Gamma logs provide a record of the radioactivity of the rock near the borehole with respect to depth. Gamma logs primarily are used for well-to-well correlation and lithology identification.

Induction logs provide a record of the conductivity of the rock (and fluid within the rock) near the borehole with respect to depth (Keys, 1997). The reciprocal of conductivity is resistivity and is provided in the well logs. The resistivity values presented in the well logs are in the same units as the capacitivelycoupled resistivity data.

\section{Resistivity Profiles}

The data for the resistivity profiles are described and presented graphically in the form of 2D sections that show contoured resistivity in gradational colors. The five resistivity sections are shown at a common resistivity scale in figure 5. Individual sections at unique scales to enhance variation within each section are in appendix 1. Gamma and induction conductivity geophysical logs are in appendix 2 .

Line 1 traverses the central part of the study site, just northeast of well MW-12 (fig. 2). At the northwestern end of the line are two zones of relatively high resistivity (24 to $38 \mathrm{ohm}-m e t e r s$ [ohm-m]) that extend from about land surface to about $12 \mathrm{ft}$ below land surface. The remainder of the section to the southeast shows relatively low resistivity (4 to 12 ohm-m).

Line 2, just northwest of line 1, shows relatively high resistivity (25 to $85 \mathrm{ohm}-\mathrm{m}$ ) over much of the section (app. 1) and reflects the highest resistivity of all the sections (fig. 5).

Highest resistivity occurs in a small zone about 5 to $10 \mathrm{ft}$ below land surface near the southeastern end of the line.

Line 3 was positioned to collect data between wells MW-9 and MW-12 just south of line 1 (fig. 2). Relatively high resistivity ( 25 to $75 \mathrm{ohm}-\mathrm{m}$ ) occurs in a zone about 5 to $15 \mathrm{ft}$ below land surface near the southeastern end of the line (app. 1). A slightly lower resistivity (20 to $30 \mathrm{ohm}-\mathrm{m}$ ) zone from about 175 to about $300 \mathrm{ft}$ from the northwestern end of the transect is indicated, which extends from land surface to about $15 \mathrm{ft}$ below land surface. The induction log for well MW-9 adjacent to line 3 shows decreasing resistivity (about 30 to about 15 ohm-m) from about 5 to about $10 \mathrm{ft}$ below land surface and increasing resistivity (about 15 to about $50 \mathrm{ohm}-\mathrm{m}$ ) from about 16 to $24 \mathrm{ft}$ below land surface (app. 2). The MW-12 induction log shows relatively constant resistivity with depth, varying from about 50 to $60 \mathrm{ohm}-\mathrm{m}$.

Line 4 is between lines 2 and 3 and the West Fork Trinity River (fig. 2). Generally lower resistivity is evident in line 4 than in lines $1-3$. Resistivity ranges from about 12 to about $16 \mathrm{ohm}-\mathrm{m}$ in a zone in the center of the section (distance about 40 to $400 \mathrm{ft}$ ) from about land surface to a depth of about $12 \mathrm{ft}$ below land surface (fig. 5; app. 1).
Line 5 is between line 2 and the West Fork Trinity River and is parallel to line 2 (fig. 2). As in line 4, resistivity in line 5 generally is lower than in lines 1-3 (fig. 5; app. 1). A very small zone of resistivity of $25 \mathrm{ohm}-\mathrm{m}$, highest for this section, is evident at about $250 \mathrm{ft}$ within the section from land surface to about 2 to $3 \mathrm{ft}$ below land surface. Beneath this small area is the zone of lowest resistivity ( $50 \mathrm{ohm}-\mathrm{m}$ or less) in the section. A zone of relatively high resistivity (15 to $18 \mathrm{ohm}-\mathrm{m}$ ) occurs at a distance of about $550 \mathrm{ft}$.

\section{Summary}

Naval Air Station-Joint Reserve Base Carswell Field (NAS-JRB) at Fort Worth, Tex., constitutes a governmentowned, contractor-operated facility that has been in operation since 1942. Contaminants, primarily volatile organic compounds (VOCs) and metals, have entered the ground-waterflow system through leakage from waste-disposal sites and are of concern to citizens and agencies responsible for water quality because of the potential for VOCs to enter the West Fork Trinity River east of NAS-JRB. During October 2004, the U.S. Geological Survey conducted a two-dimensional (2D) resistivity investigation to characterize the subsurface distribution of resistivity at a site along the West Fork Trinity River at the eastern boundary of NAS-JRB. Five capacitively-coupled resistivity profiles were collected at the site.

Two hydrogeologic units-from land surface on downward, the alluvial aquifer and the Goodland-Walnut confining unit-compose the subsurface of interest at the NAS-JRB study site. The alluvial aquifer consists primarily of clay and silt with sand and gravel channel deposits that might be interconnected. The Goodland-Walnut confining unit directly underlies the alluvial aquifer and consists of limestone, marl, shale, and clay.

Several VOCs have been detected in ground-water samples from the alluvial aquifer at NAS-JRB. A VOC of principal concern is trichloroethene (TCE). TCE is a dense nonaqueous-phase liquid and a solvent that was used for degreasing metal parts in the manufacture of airplanes immediately west of NAS-JRB.

Surface geophysical methods provide a relatively quick and inexpensive means to characterize the subsurface. Surface geophysical methods measure the physical properties of the subsurface such as electrical conductivity and resistivity, dielectric permittivity, magnetic permeability, density, and acoustic velocity. These methods can be influenced by chemical and physical properties of soil, rock, and pore fluids.

The $2 \mathrm{D}$ resistivity investigation involved a capacitivelycoupled resistivity survey and inverse modeling to obtain true or actual subsurface resistivity from apparent resistivity. Natural gamma and induction conductivity geophysical logs also were collected from four boreholes at the site.

The Geometrics TR2 OhmMapper, a mobile resistivity measuring system, was used to do the capacitively-coupled 
resistivity survey. To estimate the true resistivity, which differs from apparent resistivity or the resistivity structure where the subsurface is heterogeneous or anisotropic, or both, the apparent resistivity was processed using the inverse-modeling software program Res2Dinv software version 3.54. The results from this program were used to generate 2D sections (images of actual resistivity) referred to as inverted resistivity sections or profiles.

2D distributions (images) of resistivity along the five profiles (sections) show a wide range of resistivity values, from negligible to $85 \mathrm{ohm}-\mathrm{m}$. The two profiles nearest the West Fork Trinity River generally showed less resistivity than the three other profiles. Maximum resistivity in the two profiles nearest the river was 26.5 and $25 \mathrm{ohm}-\mathrm{m}$, whereas maximum resistivity in the three profiles farther from the river was 38,75 , and 85 ohm-m. No consistent or common patterns of resistivity are indicated in the profiles except a tendency for the relatively more resistive zones to occur within the shallower parts of the profiles, within about $10 \mathrm{ft}$ of land surface.

\section{References}

American Society for Testing and Materials, 1999, Standard guide for selecting surface geophysical methods, in Annual book of ASTM standards: West Conshohocken, Pa., v. 04.08, p. 6,429-6,499.

Geometrics, 2004, OhmMapper-Resistivity mapping: accessed October 29, 2004, at URL http://geom.geometrics. com/pub/GeoElectric/DataSheets/OhmMapDS.pdf

Geometrics, 2005, OhmMapper TR1—Operation manual: San Jose, Calif., $125 \mathrm{p}$.

HyrdroGeoLogic, Inc., 2002, Focused feasibility study of the southern lobe trichloroethene ground-water plume at former Carswell Air Force Base, Texas: Prepared for Air Force Center for Environmental Excellance, Brooks AFB, Tex., Aeronautical Systems Center, Wright Patterson Air Force Base, Ohio, and Air Force Base Closure Agency, Arlington, Va., Contract No. F41624-95-D-8005, 21 p.

Jacobs Engineering Group Inc., 1993, Installation Restoration Program (IRP) quarterly ground-water monitoring comprehensive sampling round letter report: Denver, Colo., $91 \mathrm{p}$.

Keys, W.S., 1997, A practical guide to borehole geophysics in environmental investigations: Boca Raton, Fla., CRC Press, $176 \mathrm{p}$.

Kuniansky, E.L., Jones, S.A., Brock, R.D., and Williams, M.D., 1996, Hydrogeology at Air Force Plant 4 and vicinity and water quality of the Paluxy aquifer, Fort Worth, Texas: U.S. Geological Survey Water-Resources Investigations Report 96-4091, $41 \mathrm{p}$.

Loke, M.H., 2004, Tutorial-2-D electrical imaging surveys: accessed November 2004, at URL http://www. geoelectrical.com
Loke, M.H., 2005, Description of RES2DINV software version 3.54: accessed January 2005, at URL http://www.geoelectrical.com

Powers, C.J., Wilson, Joanna, Haeni, F.P., and Johnson, C.D., 1999, Surface-geophysical investigation of the University of Connecticut landfill, Storrs, Connecticut: U.S. Geological Survey Water-Resources Investigations Report 99-4211, $34 \mathrm{p}$.

RUST Geotech, 1995a, Air Force Plant 4, feasibility study, sections 1-5, v. I: Prepared for U.S. Air Force, Headquarters Aeronautical Systems Center, Wright-Patterson Air Force Base, Ohio, Department of Energy contract no. DE-AC04-861D12584, GJPO-WMP-86, 413 p.

RUST Geotech, 1995b, Air Force Plant 4, feasibility study, appendix A-D, v. II: Prepared for U.S. Air Force, Headquarters Aeronautical Systems Center, Wright-Patterson Air Force Base, Ohio, Department of Energy contract no. DE-AC04-861D12584, GJPO-WMP-86, 145 p., 5 pls.

RUST Geotech, 1995c, Air Force Plant 4, remedial investigation and preliminary assessment/site inspection report, v. I: Prepared for U.S. Air Force, Headquarters Aeronautical Systems Center, Wright-Patterson Air Force Base, Ohio, Department of Energy contract no. DE-AC04-861D12584, GJPO-WMP-75, 545 p.

RUST Geotech, 1995d, Air Force Plant 4, remedial investigation and preliminary assessment/site inspection report, v. II: Prepared for U.S. Air Force, Headquarters Aeronautical Systems Center, Wright-Patterson Air Force Base, Ohio, Department of Energy contract no. DE-AC04-861D12584, GJPO-WMP-76, 34 pls.

Shah, S.D., 2004, Development of a geodatabase and conceptual model of the hydrogeologic units beneath Air Force Plant 4 and Naval Air Station-Joint Reserve Base Carswell Field, Fort Worth, Texas: U.S. Geological Survey Scientific Investigations Report 2004-5062, 77 p.

U.S. Air Force, Aeronautical Systems Center, 1995, Proposed plan of action for U.S. Air Force Plant 4 superfund site, Fort Worth, Texas: Wright-Patterson Air Force Base, Ohio, U.S. Air Force, Headquarters Aeronautical Systems Center, Environmental Management Directorate, 43 p.

U.S. Air Force, Center for Environmental Excellence, 1997, Technical Report for the ERPIMS 2.0 database model of the Environmental Resources Program Information Management System (ERPIMS): Brooks Air Force Base, Tex., U.S. Air Force, 112 p.

U.S. Army Corps of Engineers, 1986, Investigation of groundwater pollution at Air Force Plant 4, Fort Worth, Texas, October 1986: Fort Worth, 28 p., 8 pls.

U.S. Army Corps of Engineers, 1995, Engineering and design, geophysical exploration for engineering and environmental investigations-Electrical and electromagnetic methods: Engineering Manual 1110-1-1802, chap. 4, $57 \mathrm{p}$. 


\section{Appendix 1-Field Inversion Results of Capacitively- Coupled Data, NAS-JRB Study Site, Fort Worth, Texas}


Blank Page 


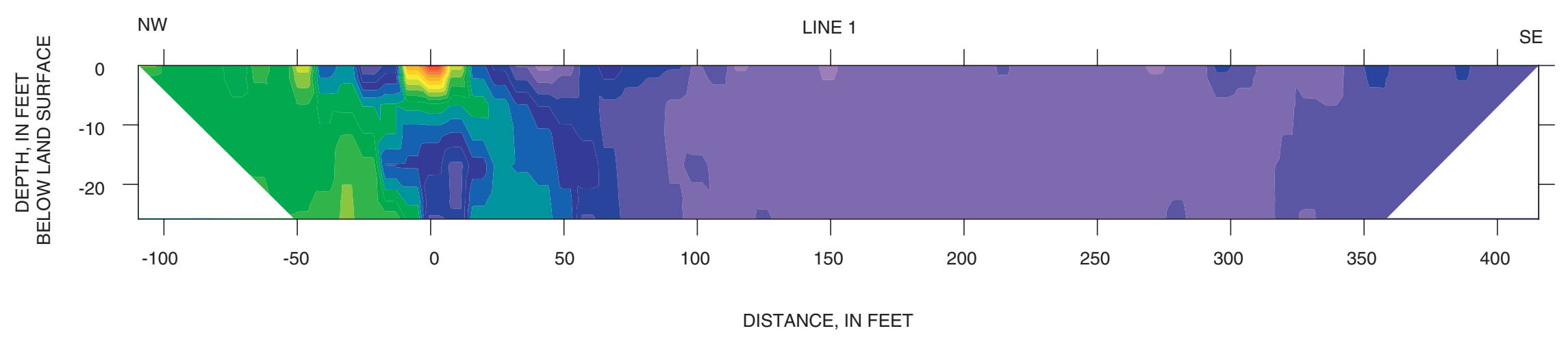

\section{EXPLANATION}

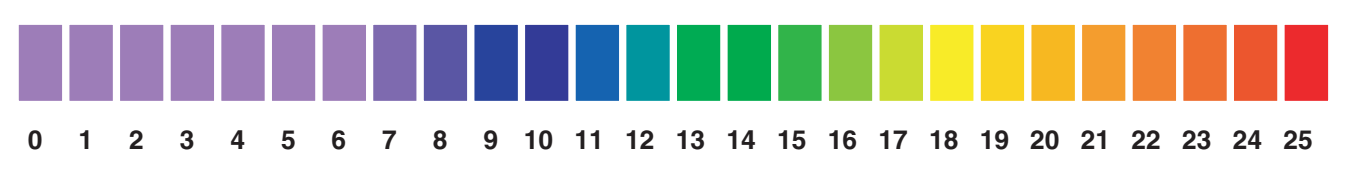

Resistivity, in ohm-meters

Appendix 1.1 Field inversion results of capacitively-coupled data, NAS-JRB study site, Fort Worth, Texas, line 1. 

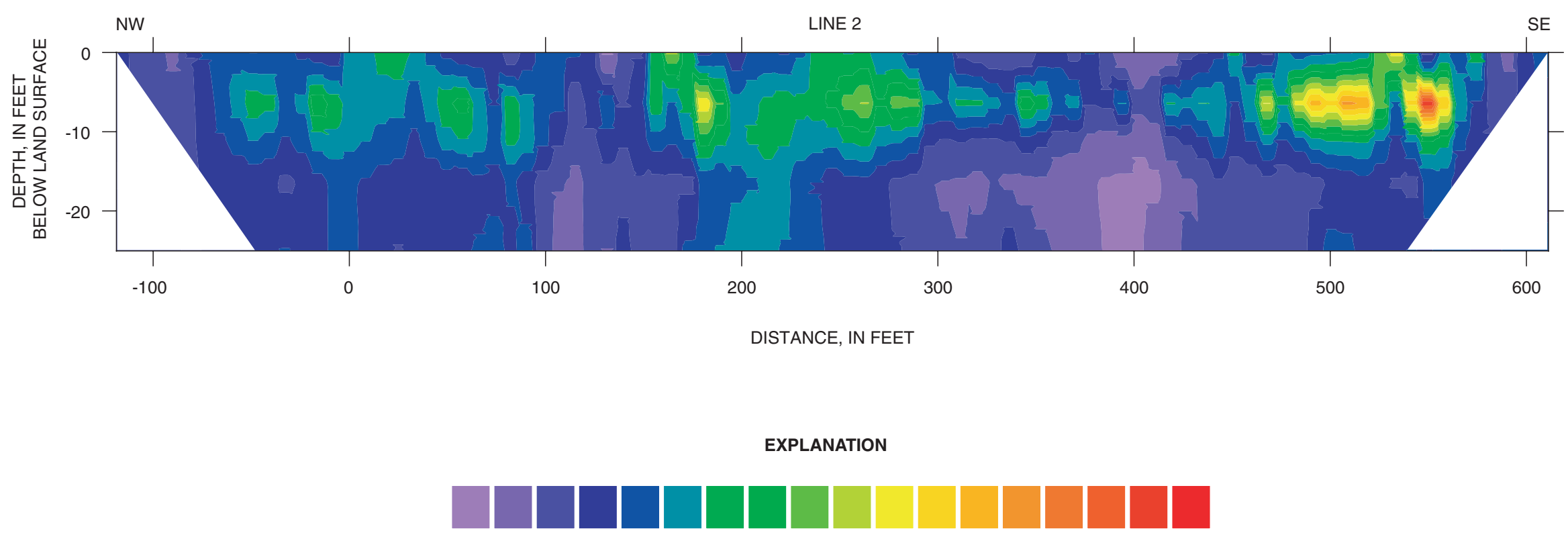

$\begin{array}{llllllllllllllllll}0 & 5 & 10 & 15 & 20 & 25 & 30 & 35 & 40 & 45 & 50 & 55 & 60 & 65 & 70 & 75 & 80 & 85\end{array}$

Resistivity, in ohm-meters

Appendix 1.2 Field inversion results of capacitively-coupled data, NAS-JRB study site, Fort Worth, Texas, line 2. 


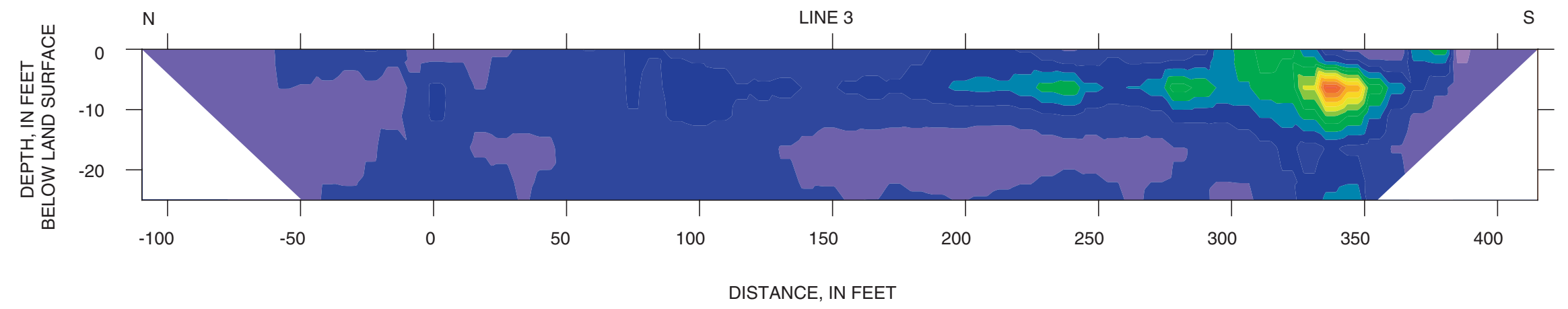

\section{EXPLANATION}

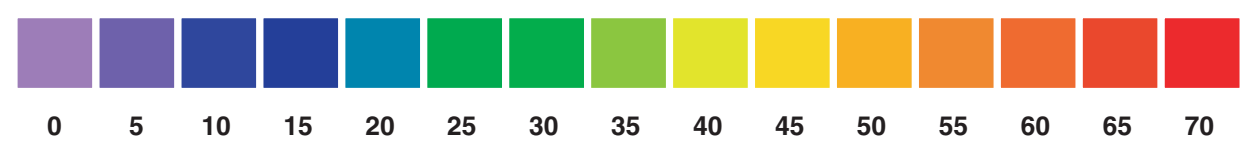

Resistivity, in ohm-meters

Appendix 1.3 Field inversion results of capacitively-coupled data, NAS-JRB study site, Fort Worth, Texas, line 3. 

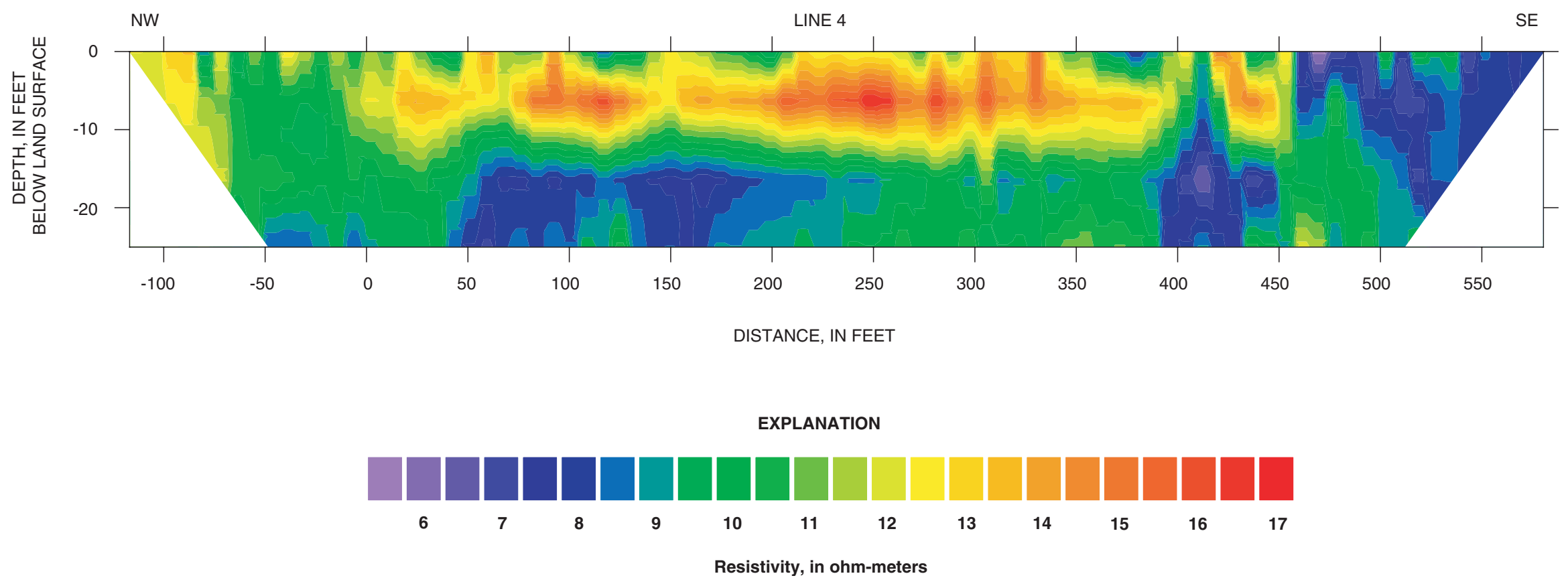

Appendix 1.4 Field inversion results of capacitively-coupled data, NAS-JRB study site, Fort Worth, Texas, line 4. 

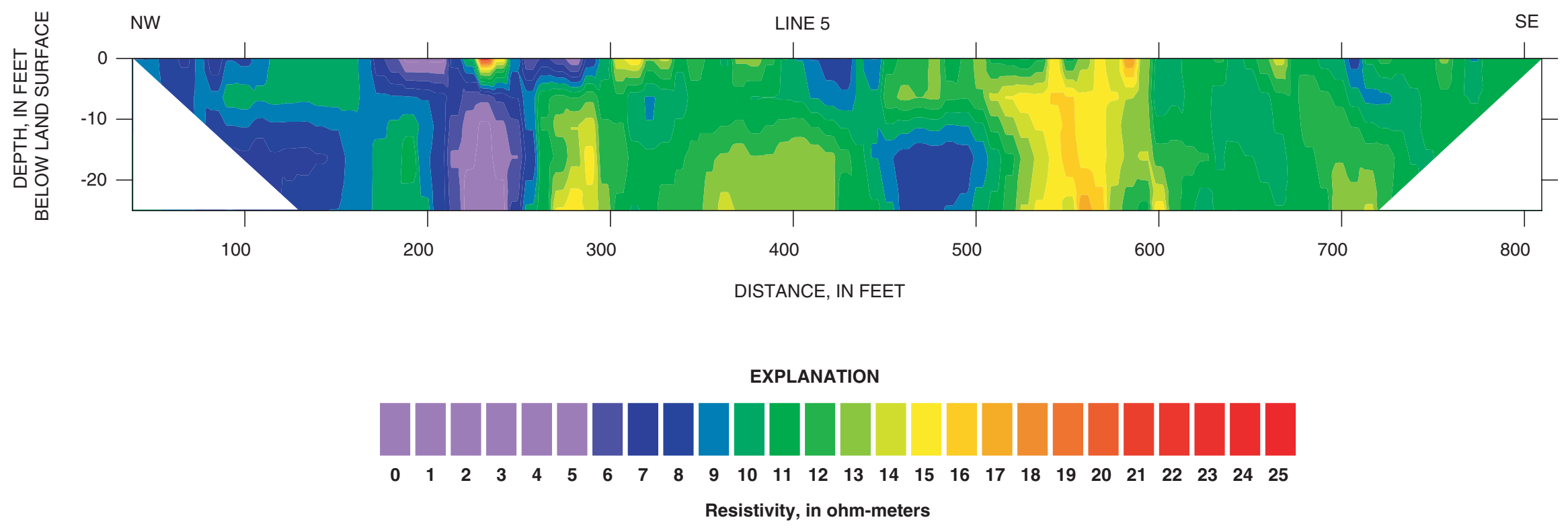

Appendix 1.5 Field inversion results of capacitively-coupled data, NAS-JRB study site, Fort Worth, Texas, line 5. 
Blank Page 


\section{Appendix 2 - Natural Gamma and Induction Conductivity Borehole Geophysical Logs, NAS-JRB Study Site, Fort Worth, Texas}


Blank Page 
WELL MW-09
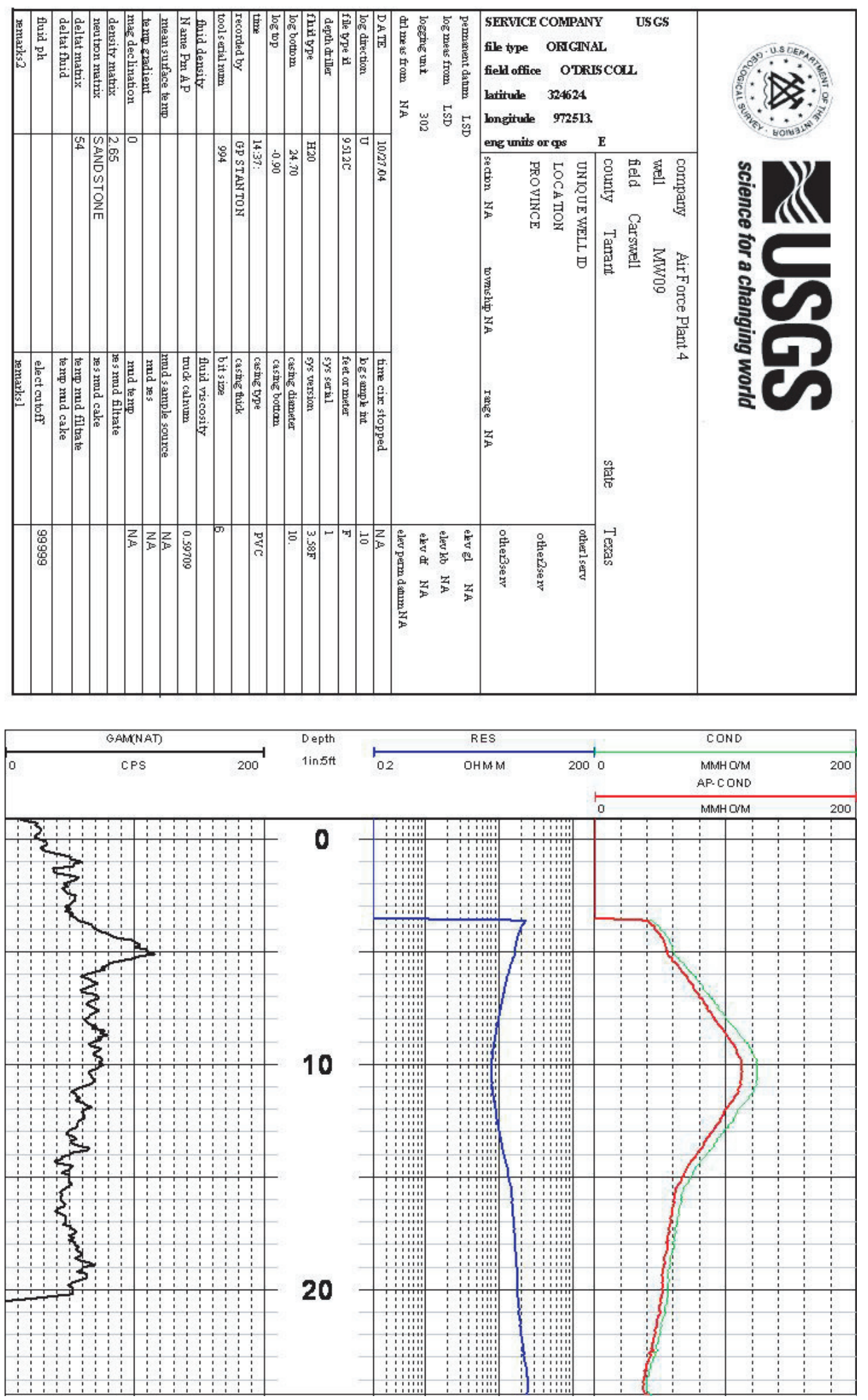

Appendix 2.1 Natural gamma and induction conductivity borehole geophysical logs, NAS-JRB study site, Fort Worth, Texas, well MW-09. 
WELL MW-12
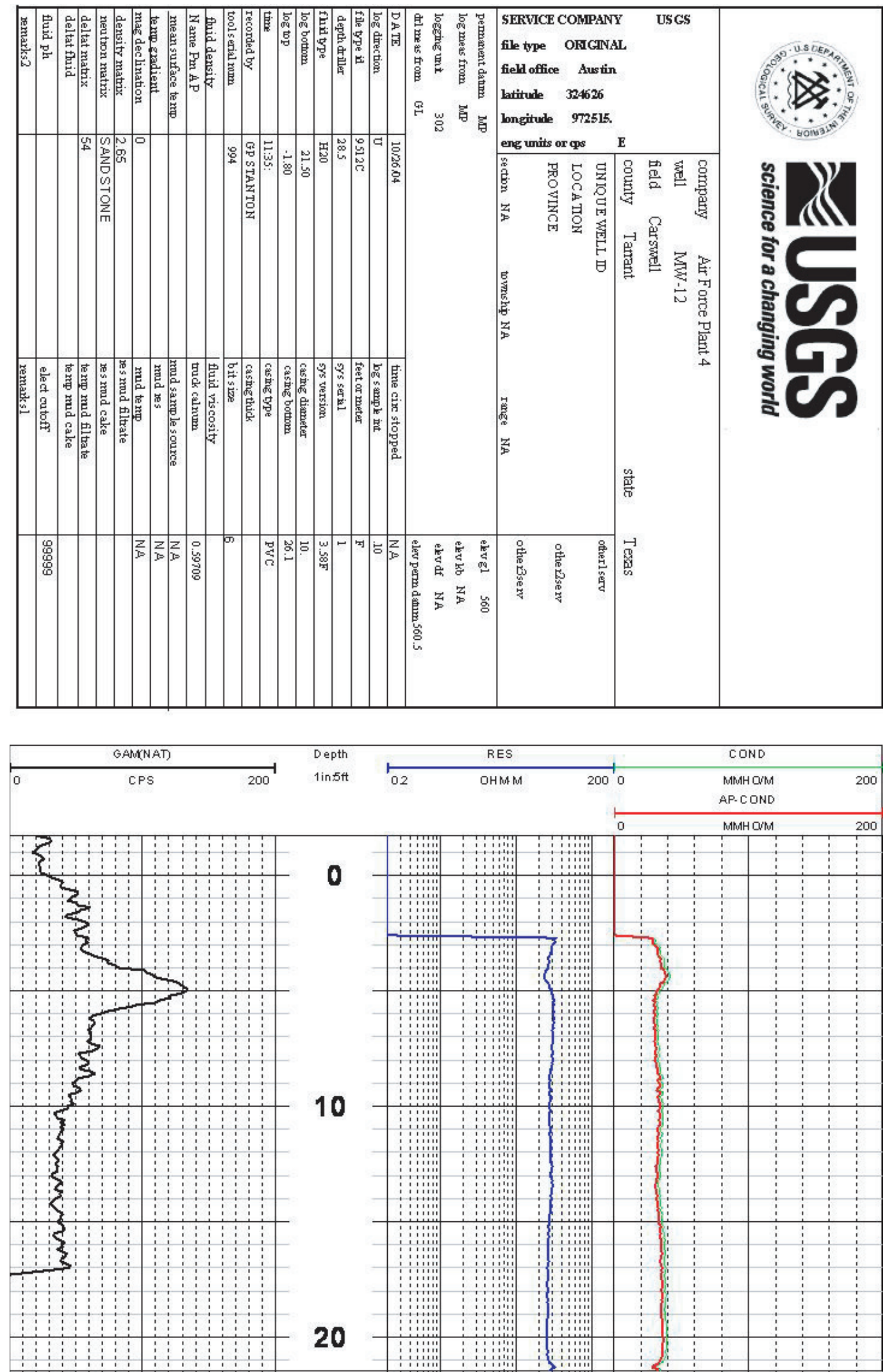

Appendix 2.2 Natural gamma and induction conductivity borehole geophysical logs, NAS-JRB study site, Fort Worth, Texas, well $\mathrm{MW}-12$ 
WELL WHGLTA036
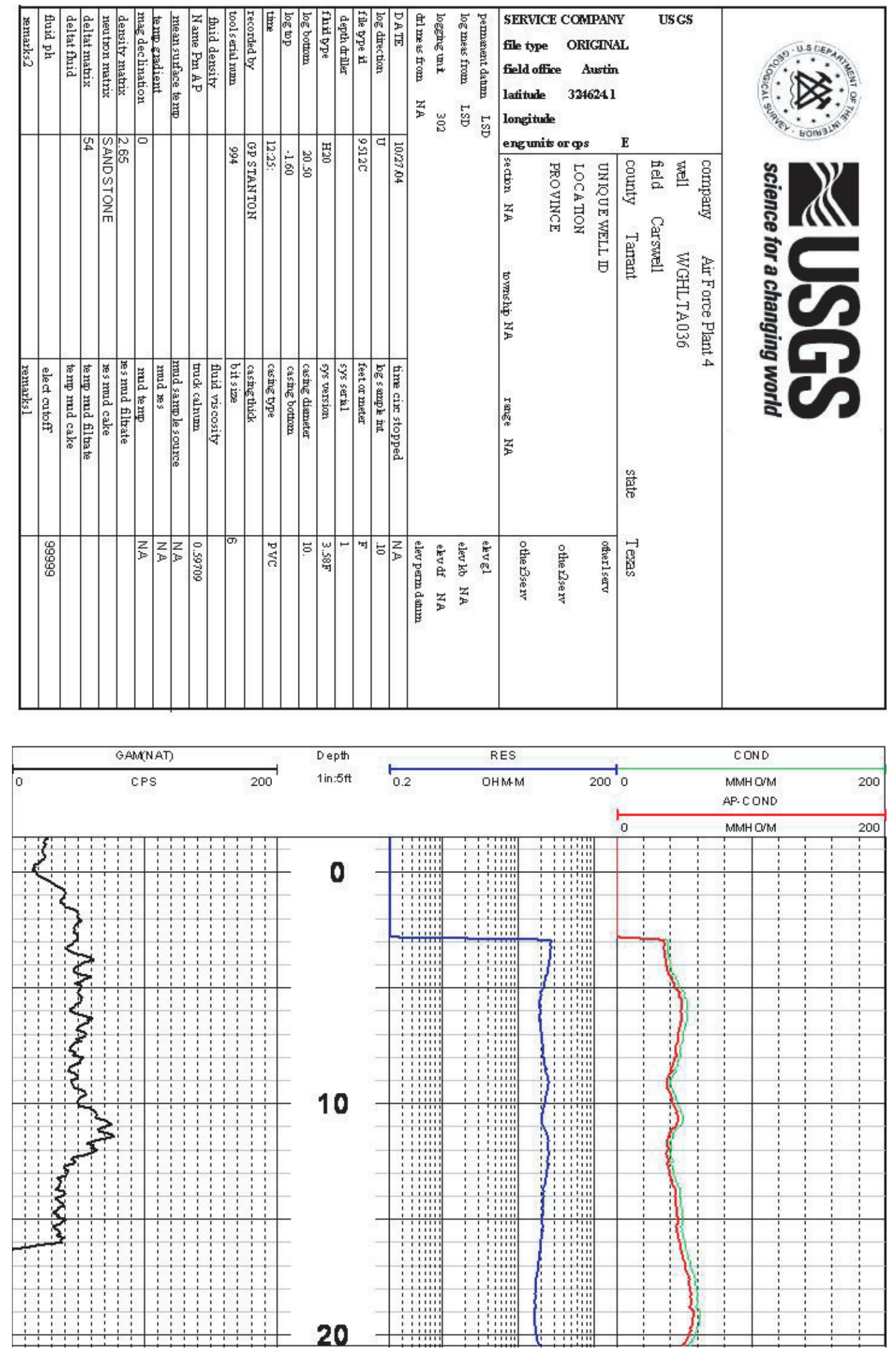

Appendix 2.3 Natural gamma and induction conductivity borehole geophysical logs, NAS-JRB study site, Fort Worth, Texas, well WHGLTA036. 
WELL WHGLTA037
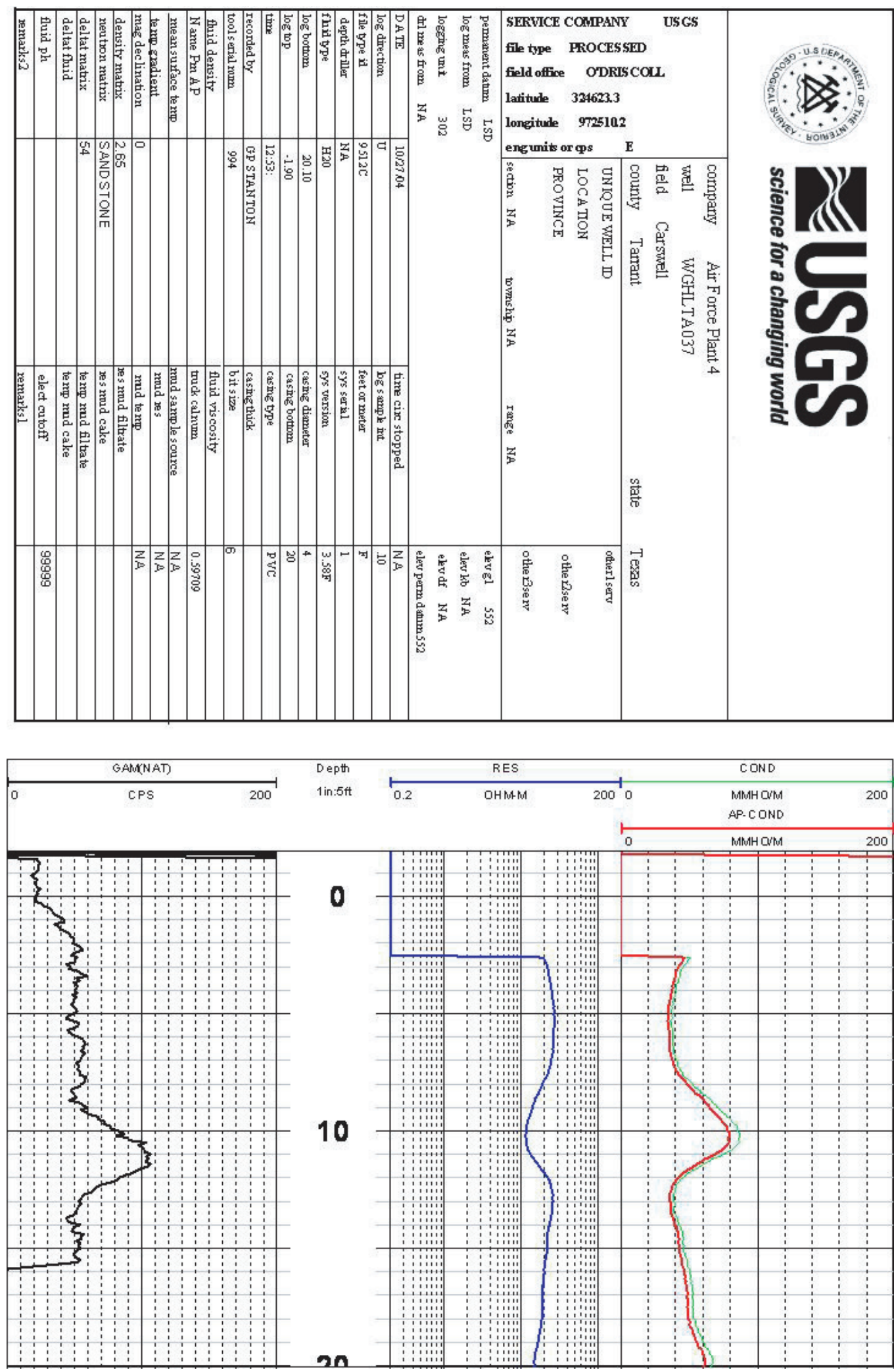

Appendix 2.4 Natural gamma and induction conductivity borehole geophysical logs, NAS-JRB study site, Fort Worth, Texas, well WHGLTA037. 
Prepared by the USGS Texas Water Science Center:

8027 Exchange Drive

Austin, TX 78754-4733

Information regarding water resources in Texas is available at http: //tx.usgs.gov/ 